\title{
A STUDY OF COMPOSITE INDEX: WITH SPECIAL CONTEXT TO GOND TRIBE OF CENTRAL INDIA Shyam Sunder Singh ${ }^{1}$, Akhand Sharma ${ }^{2 *}$ \\ ${ }^{1,2}$ Research Scholar, Department of Education, Doctor Harisingh Gour Vishwavidyalaya, (A Central University) Sagar (M.P.), India.

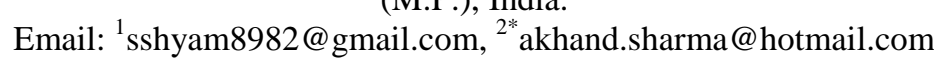

Article History: Received on $06^{\text {th }}$ September 2019, Revised on $29^{\text {th }}$ November 2019, Published on $31^{\text {st }}$ December 2019

\begin{abstract}
Purpose of the study: The purpose of the study is to reveal the facts that fall under composite index; socio-economic, health and education status of Gond Tribe in Betul district of Madhya Pradesh. The study exposed the facts whether the tribal people are aware and benefitted from the Government programs related to Education and Health running in these areas or not.

Methodology: The study has used purposive and systematic sampling for selecting the sample of 154households. SPSS 21 and AMOS are used for data analysis. The Multinomial Logistic Regression, Correlation and Regression Analysis and Multiple Correlation and Regression Analysis, are used for analyzing the data. The percentage-wise analysis is used for analyzing other facts related to socio-economic, health and education services.

Main Findings: Medical and educational services are not satisfactory in the tribal region. The result reveals that there is a significant correlation between household income and the health status of the family. The study explored households whose incomes are less than five thousand in such families' adults are suffering from chronic diseases whereas children are facing malnutrition problems.
\end{abstract}

Applications of this study: The study has discussed specific ideas that will help the government in implementing programs/ schemes so that it will help in improvising the quality of life of the tribal people.

Novelty/ Originality of this study: The work is a highly original and innovative and studied composite index in context to the Gond tribe, it reflects the ground-level reality of the welfare programs which are running for the benefits of the tribal.

Keywords: Composite Index, Central India, Socio-economic, Tribal, Gond.

\section{INTRODUCTION}

In Hindu epics, like Ramayan and Mahabharat three major Indian tribes, Bhil, Kol, and Gond have been widely appreciated. Gond tribe is widely scattered in the Central part of India especially in the states of Chhattisgarh and Madhya Pradesh. A majority of tribal population is concentrated in the nine provinces of India; Andhra Pradesh, Chhattisgarh, Gujarat, Jharkhand, Madhya Pradesh, Maharashtra Odisha, Rajasthan, and West Bengal. Nearly12\% inhabit in the northeast region, approximate 5\% in the southern region and 3\% in the northern provinces of India. According to Census 2011 , the total population of scheduled tribes was $10,428,1034$ persons constituting $8.6 \%$ of the population of the country. The government of India records 698 scheduled tribes in India whereas the census of India 2011 notified 705 individual groups as STs as listed in annexure $1 \mathrm{~b}$ (List of notified ST).

\section{SCHEDULED TRIBE IN INDIA}

The term 'Scheduled Tribes' was coined by Dr. Ghurie and it was used for the first time in India's census report of 1951. 'Scheduled Tribes' was included in the constitution vide Article342 but in the Constitution of India, the term 'Tribe' has not been defined (Inflibnet, p.2). There are around 705 Scheduled Tribes notified under Article 342 of the constitution of India which accounts for $8.6 \%$ of the country's population (Tribal Health in India, 2018, p.1). Various tribes are found in more than one province of India. The largest numbers of STs nearly 62 are concentrated in the state of Odisha. The President of India, may with respect to any state or union territory and where it is a state after consultation with the Governor thereof, notify tribes or tribal communities or parts of these as STs, as mentioned in clause (1) of Article 342. It is notified in Clause (2) of the article, which empowers the parliament to pass a law to include in or exclude any tribe or tribal community or parts of these from the current list of scheduled tribes.

The distribution of scheduled tribe population in proportion to total population of the province in descending order is given as; Madhya Pradesh stands first with $14.7 \%$ followed by Maharashtra (10.10\%), Odisha (9.20\%), Rajasthan (8.90\%), Gujarat (8.6\%), Jharkhand (8.3\%) and Chhattisgarh $(7.50 \%)$. The states of Madhya Pradesh, Chhattisgarh, Maharashtra, Odisha, Jharkhand, and Gujarat accounted for more than half of the scheduled tribe population (Tribal Health in India, 2018, p.12). On the basis of the above statistics pie chart has been drawn which reflects scheduled tribes population in specific states of India. 


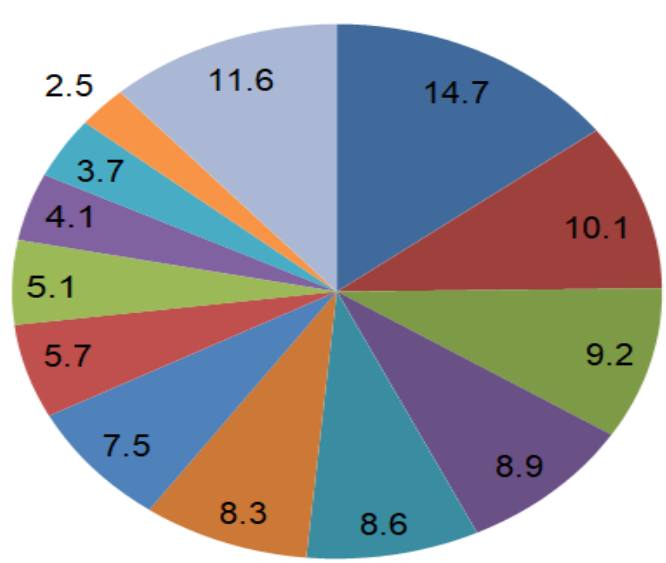

$$
\begin{aligned}
& \text { - MP } \\
& \text { - Maharashtra } \\
& \text { - Odisha } \\
& \text { - Rajasthan } \\
& \text { - Gujarat } \\
& \text { - Jharakhand } \\
& \text { - Chhattisgarh } \\
& \text { - Andhra P. } \\
& \text { - WB } \\
& \text { - Karnataka } \\
& \text { - Assam }
\end{aligned}
$$

Figure 1: Scheduled Tribes Population (\%)

In India, 90 districts are identified where the tribal population is more than $50 \%$ of the total population whereas it has found that in 62 districts the tribal population is more than $25 \%$ but less than $50 \%$ of the total population in that region. In the state of Madhya Pradesh, the tribal population in six districts has above 50\% whereas in thirteen districts it is more than $25 \%$ but less than $50 \%$ of the total population. Census of India, 2001 reflected that the Bhil $(12,689,952)$ tribe has the largest population followed by Gond $(10,859,422)$, the Santal $(58,38,018)$ and the Mina $(38,000,02)$.

\section{Gond Tribe}

Gond is the second populous tribe in India after Bhils. 'Gondavana' region is known as 'the land of Gonds' the easternmost districts of Madhya Pradesh, formerly known as the Middle Region of India. Madhya Pradesh and Chhattisgarh have the largest concentration and dense population of Gond tribes heavily resides in the areas of Betul, Hoshangabad, Chhindwara, Balagahat, Shahdol, Mandla, Dindori, Sagar and Damoh districts of Madhya Pradesh. Language belonging to a Dravidian family is one spoken by tribes such as Gond.

In the Betul district of Madhya Pradesh Gonds are more cultured or influenced by Hindu religion some have adopted the Hindu religion and start living in closed villages apart from their castes and tribes. In Betul, most of the Gonds in some or other ways engaged in agricultural and animal husbandry activities.

\section{Composite Index}

The composite index comprises three components namely; socio-economic, health and education. In the proposed study under Socio-economic; household income, size of the family, land holdings and condition of houses, Health; status of the household health and condition of health services and programs running and under Education; status of household education and condition of educational services and programs running in the specified region has been revealed by the present study.

\section{SCENARIO OF COMPOSITE INDEX: SOCIO-ECONOMIC, HEALTH AND EDUCATION STATUS IN TRIBAL BELTS OF INDIA}

\section{Scheduled Tribes?}

The communities who are scheduled in accordance with Article 342 of the constitution of India come under scheduled tribes. The Lokur Committee (1965) has identified some essential characteristics for this community as:

- Indications of primitive traits

- Distinctive culture

- The shyness of contact with the community at large

- Geographical isolation; and

- Backwardness

I. Socio-economic status:

Socio-economic status of the tribal people residing in different parts of India is discussed below:

\section{A. Household Main Source of drinking water:}

The main sources of drinking water in tribal areas of different parts in India are shown in table 1. 
Table 1: Sources of Drinking Water in the Tribal States

\begin{tabular}{lllll}
\hline \multicolumn{1}{c}{ Area } & Total No. of ST HH & $\begin{array}{c}\text { Treated Tap water, } \\
\text { Hand pump, etc. }(\%)\end{array}$ & $\begin{array}{c}\text { Untreated tap water, } \\
\text { covered wells, tube- } \\
\text { wells } \\
\text { Borewell etc. }(\%)\end{array}$ & $\begin{array}{c}\text { Uncovered well } \\
\text { Springs, Lakes, } \\
\text { Ponds, Canals, Other } \\
\text { sources } \\
\text { etc. }(\%)\end{array}$ \\
\hline India & & 19.58 & 26.60 \\
\hline Rajasthan & $18,33,29,105$ & 53.82 & 14.86 & 25.93 \\
\hline Jharkhand & $17,18,359$ & 59.21 & 4.79 & 43.29 \\
\hline Odisha & $22,40,142$ & 49.92 & 24.18 & 28.85 \\
\hline Chhattisgarh & $17,47,575$ & 46.97 & 8.30 & 28.30 \\
\hline MadhyaPradesh & $32,13,683$ & 69.60 & 7.15 & 24.93 \\
\hline Maharashtra & $24,45,645$ & 64.55 & 21.62 & \\
\hline
\end{tabular}

Source: Census of India, 2011

\section{B. Condition of Houses:}

The given Table $2 \boldsymbol{A}$ represents the current data related to the condition of houses in India and the state of Madhya Pradesh by NSSO (2018) whereas Table $2 \boldsymbol{B}$ represents overall India to the condition of houses of Scheduled tribes in India. According to the 2011 census, $38.84 \%$ of scheduled tribes of M.P. have good houses, 55.12\% have livable and $6.04 \%$ have dilapidated houses (Statistical Profile of ST in India, 2013). There are several states where the condition of houses (\%) falling below the all India level, Madhya Pradesh (36.60\%) is one of them.

Table 2A: Comparative Condition of Houses in India and M.P.

\begin{tabular}{lllllll}
\hline \multirow{2}{*}{ Area } & \multicolumn{2}{l}{ Condition of Houses (\%) } & \multicolumn{3}{l}{ Dilapidated } \\
\cline { 2 - 7 } & Good & Livable & M.P. & India & M.P. \\
\hline Category & India & M.P. & India & 56.10 & 14.90 & 22.00 \\
\hline Rural & 34.70 & 22.00 & 50.40 & & 6.90 & 6.70 \\
\hline Urban & 58.20 & 54.50 & 35.00 & 38.70 & & \\
\hline
\end{tabular}

Source: NSSO $76^{\text {th }}$ Round: Drinking Water, Sanitation, Hygiene and Housing Condition in India, July- Dec.2018

Table 2B: Comparative Condition of Houses in Tribal Areas

\begin{tabular}{lllllll}
\hline \multirow{2}{*}{ Area } & \multicolumn{2}{l}{ Condition of Houses (\%) } & & & \\
& \cline { 2 - 7 } & Good & & Livable & \multicolumn{3}{l}{ Dilapidated } \\
\hline Category & India & ST & India & ST & India & ST \\
\hline Rural & 45.91 & 37.61 & 47.58 & 55.85 & 6.51 & 6.55 \\
\hline Urban & 68.44 & 59.69 & 28.67 & 35.93 & 2.88 & 4.39 \\
\hline
\end{tabular}

Source: Census of India, 2011, Office of the Registrar General

\section{Distribution of Land Ownership Holdings among HH ofSTs:}

The share of land owned in rural India by ST was $13.06 \%$ and the average area of land owned per household was 0.650 hectares (NSS $70^{\text {th }}$ Round, Dec.2013, p.i). The given tabular data reflects the size of land holdings hold by ST households.

\section{EDUCATION}

About $41 \%$ of the ST population in India is illiterate as compared to $31 \%$ of the non- scheduled tribe population, while $35 \%$ of tribal people had attained primary education and less than $2 \%$ had received higher education. Nationally only $6.7 \%$ of the ST population above 18 years of age have completed 12 years of education. 
Table 3: Distribution of Landholdings among ST

\begin{tabular}{|c|c|c|c|}
\hline \multirow{2}{*}{ Area } & \multirow{2}{*}{$\begin{array}{l}\text { Size of Land Holdings } \\
\text { (in ha.) }\end{array}$} & \multicolumn{2}{|c|}{ Percentage of Household } \\
\hline & & $\overline{\mathbf{A L L}}$ & ST \\
\hline & Landless $(<=0.002)$ & 7.41 & 9.41 \\
\hline & Marginal (0.002-1.00) & 75.42 & 68.83 \\
\hline \multirow[t]{4}{*}{ RURAL } & Small (1.00-2.00) & 10.00 & 14.64 \\
\hline & Semi-medium (2.00-4.00) & 5.01 & 5.74 \\
\hline & Medium (4.00-10.00) & 1.93 & 1.36 \\
\hline & Large $(>10.00)$ & 0.24 & 0.03 \\
\hline TOTAL & & 100 & 100 \\
\hline
\end{tabular}

Source: $\underline{\text { NSSO } 70^{\text {th }} \text { Round (Jan.-Dec. 2013) }}$

\section{A. Literacy Rate}

The literacy rates of scheduled tribes during different census periods are shown below:

Table 4: Literacy Rate among STs during different Census

\begin{tabular}{lllllll}
\hline Year & $\begin{array}{l}\text { Scheduled } \\
\text { (STs) }\end{array}$ & & Tribes & TOTAL & INDIA & TOTAL \\
\cline { 2 - 6 } & Male & Female & & Male & Female & \\
\hline 1981 & 24.52 & 8.04 & 16.35 & 56.38 & 29.76 & 43.57 \\
\hline 1991 & 40.65 & 18.19 & 29.60 & 64.13 & 39.29 & 52.21 \\
\hline 2001 & 59.17 & 34.76 & 47.10 & 75.26 & 53.67 & 64.84 \\
\hline 2011 & 68.50 & 49.40 & 59.00 & 80.90 & 64.60 & 73.00 \\
\hline
\end{tabular}

Source: Census of India, 2011, Office of the Registrar General

\section{B. Gross Enrolment Ratio (GER)}

Gross Enrolment Ratio for different levels of education for scheduled tribes in India as well as for the state of Madhya Pradesh is shown in the given table.

Table 5A: Gross Enrolment Ratio of ST in India.

\begin{tabular}{llll}
\hline Classes & ST (India) & TOTAL \\
\cline { 2 - 3 } & Boys & Girls & \\
\hline I-V & 107.80 & 105.70 & 106.70 \\
\hline VI-VIII & 95.40 & 98.20 & 96.70 \\
\hline IX-X & 73.70 & 75.40 & 74.50 \\
\hline XI-XII & 43.80 & 42.40 & 43.10 \\
\hline
\end{tabular}

Source: Educational Statistics at a Glance (2015-16), MHRD

Table 5B: Gross Enrolment Ratio of ST in the State of M.P.

\begin{tabular}{llll}
\hline Classes & ST (M.P.) & TOTAL \\
\cline { 2 - 3 } & Boys & Girls & 93.56 \\
\hline I-V & 96.33 & 90.67 & 91.86 \\
\hline VI-VIII & 90.42 & 93.43 & 64.85 \\
\hline IX-X & 63.09 & 66.79 & 28.42 \\
\hline XI-XII & 28.56 & 28.28 & \\
\hline
\end{tabular}

Source: Educational Statistics at a Glance (2015-16), MHRD

\section{Tribal Health and Health Care}

The report, Tribal Health in India (2013) highlights the issues related to tribal health. Some of the findings of this report are: 
i. $42 \%$ of the tribal children are underweight which is 1.5 times higher than non-tribal children.

ii. Tribal people account for $30 \%$ of all cases of malaria, $50 \%$ of all malaria-related deaths is that of tribal people.

iii. 703 out of $10 \mathrm{~K}$ tribal people suffered from tuberculosis.

iv. $18.5 \%$ of the tribal people suffered from leprosy

v. The estimates published in The Lancet 2016, show that life expectancy at birth for the ST population in India is 63.9 years as against 67 years for the general population.

Tribal people face the 'triple burden' of diseases, apart from high rates of malnutrition and communicable diseases (TB, Leprosy, HIV, etc.), due to changing lifestyles and environment which lead to rising in non-communicable diseases; Cancer, Diabetes and Hypertension (State ofHealth and Health Care in Tribal Areas, 2018, p.33). According to the report published in 'The Hindu', Taking healthcare to India's remote tribes (2014), health problems prevalent in tribal areas include endemic infectious diseases like malaria, tuberculosis, and diarrheal diseases, apart from malnutrition and anemia. There are ten health problems that affect the tribal people disproportionately and keep them from enjoying a healthy and productive life, malaria, malnutrition and child mortality are the most common health problems among tribal peoples (Tribal Health in India, 2018, p.121).

\section{Mortality Rate}

The comparative statistics related to mortality rates in specific tribal states to India are shown as:

Table 6: Mortality Rate among STs

\begin{tabular}{lllll}
\hline \multirow{2}{*}{ State } & \multicolumn{4}{l}{ Infant Mortality Rate (IMR) <5 Mortality Rate (U5MR) } \\
\cline { 2 - 5 } & All & ST & All & ST \\
\hline All India & 40.70 & 44.40 & 49.70 & 57.20 \\
\hline Chhattisgarh & 54.00 & 65.80 & 64.30 & 80.00 \\
\hline Jharkhand & 43.80 & 46.80 & 54.30 & 64.00 \\
\hline Madhya Pradesh & 51.20 & 58.90 & 64.60 & 78.50 \\
\hline Maharashtra & 23.70 & 32.80 & 28.70 & 41.40 \\
\hline Odisha & 39.60 & 51.80 & 48.10 & 65.60 \\
\hline Rajasthan & 41.30 & 39.50 & 50.70 & 57.80 \\
\hline
\end{tabular}

Source: NFHS-4, MoHFW (2015-16)

The infant mortality rate (IMR) and U5MR for the statistics related to India and the concerned

States can be sighted from the above source whereas for the data regarding Scheduled tribe can be accessed from :http://rchiips.org/nfhs/NFHS-4Report.shtml for the respective state report.

\section{STATEMENT OF THE PROBLEM}

The proposed study is to examine the composite index; economic, health and education status of Gond Tribe residing in Betul district of Madhya Pradesh.

\section{NEED \& SIGNIFICANCE OF THE STUDY}

According to the census of India, 2011, 15.3 million (14.69\%) scheduled tribes reside in the state of Madhya Pradesh. Gond tribe is largely found in the state of Madhya Pradesh. According to the Statistical Profile of S.T. in India 2013 Report, 1619 villages in Madhya Pradesh having 91-100\% tribal population, Betul district is one of them where Gond household found in large numbers. The study is an intensive attempt to explore the facts related to the composite index of Gond Tribe residing in Betul district, where the understudy tribe is densely populated.

The understudy will provide suggestions to the concerned government so that they will implement the programs effectively for the tribal welfare, in order to improve the quality of life of tribal residing across India.

\section{LITERATURE REVIEW}

Sharma.\&Dubey. (2017) conducted a study to examine the health and education status of the Gond tribe of Banda Tehsil, Sagar, and Madhya Pradesh. The study reveals the fact that HH_Edu was not a unique predictor whereas HH_Y was a unique predictor for studying HH_Stat (health satisfaction level). In the second case, HH_Edu was not a unique predictor whereas HH_Y was a unique predictor evaluating Edu-Stat (education satisfaction level). $82 \%$ of the respondents grade poor/worst medical services in their region whereas $97 \%$ of respondents claim that they are not availing benefits from government medical services/ programs. $62 \%$ of respondents claimed that they are availing benefits from government educational programs. The study concluded that Gond tribal people in Sagar are not aware of programs running by the 
government for their welfare; besides this illiteracy as the major factor apart of its lack of transportation facilities from their villages to suburban areas was also one of them.

Dash. (2013) conducted a study on tribal education and the health of rural Odisha. The study was based on reports focusing on education and health facts by various government institutions and international organizations. The result highlighted that there is a positive relationship between maternal education and the better the health of children. The study year 2009 reveals the fact that out of 98 households, 35 had borrowed money at a 95\% rate of interest to meet their health expenditure. Moneylender interest charges on such loans varied from $36 \%$ to $120 \%$ per annum. 95\% SC/ST households borrowed money to meet their healthcare expenditure and for this, they have to keep their cultivated land as collateral which they lost in order to repay their debt. The study concluded that Poverty and illiteracy are the two main factors responsible for the debt positions of depriving STs.

Dhargupta.et al. (2009) carried out work to study the effect of socio-economic parameters on the health status of four specific tribes of West Bengal. The study was conducted to examine the socio-economic variables for tribes from Jalpaiguri and Puruliya district of West Bengal. The study reveals the fact that respondents belong to Sabar tribes, as they were illiterate, mainly involved in labor classwork, due to which their income was very low (up to 1000/month). Number of Children in the family was significant at $5 \%$ level of significance for the few selected tribes. Religion, age, and sex had no significant difference from their mean scores among the four tribes. The result concluded that the economic status of Santal tribes was much better than the other three tribes, but the education status of Lodha was far better than the other three ones.

Mitra.et al. (2007) explore the facts related to the nutritional and health status of tribal preschool children of Chhattisgarh. The sample was selected from four villages of the Korba district. Diet survey was carried out by weighing method (Rao.,1986) anthropometric measurement (height and weight) were measured following IBP recommendations (Weiner \& Lourie,1981). A nutritional deficiency survey was conducted on each child as recommended by WHO, 1995. The result shows that nutrient intake by Gond and Kawar pre-school children signified a deficiency in almost all nutrients except protein, thiamine and niacin intake as compared to RDA of India. The results show that 53.33\% of Gond girls were suffered by the paleness of eye, dental carries, and bleeding gum, it was observed that nutrients intake was very much lower among Gond and Kawar pre-school children as compared to other tribal children. The study concluded that insufficient nutrition intake by children was due to the mother's illiteracy.

Pradhan.\& Sharma (2011) conducted a cross-sectional study to examine the nutritional status of Bhil tribal children, Indore district of Madhya Pradesh. The study observed 24 hours of dietary intakes of children. The indices of nutritional status (weight for age, height for age and weight for height) were calculated in SD values (termed as $\mathrm{Z}$ scores), using reference median as recommended by WHO, 1995. The mean intake of energy and protein was calculated and finally compared with RDA for Indians (ICMR, 1990).

The prevalence of underweight (<- 2 SD weight for age) was found to be slightly higher in the age group (4-12 years) in girls $(72.7 \%)$ than boys $(66.20 \%)$. The prevalence of stunting (<- 2 SD height for age) in both sexes are almost similar in the age group of 4-12 years. The prevalence of wasting (<- 2 SD weight for height) was relatively higher in girls $(61.10 \%)$ than boys $(56.40 \%)$. In the case of the average intake of nutrients among Bhil children, all foods except cereals (maize) were lower along with protein and energy consumed among children in different age groups as recommended by RDA. The study suggested that by imparting necessary health education to children, parents and school teachers, we can raise the health and nutritional status among Bhil tribes.

\section{OBJECTIVES}

The prime objective of the study is to explore the facts related to the composite index of Gond Tribe residing in the Betul district of Madhya Pradesh.

Specific objectives of the proposed study are:

To study whether the final model is more significant than the null model.

i. To study whether there is any relationship exists between household income and family members with the health status of the family.

ii. To study whether there is any correlation exists between household income and health status of the family

iii. To study whether there is any correlation exists between household income and members in the family with the education status of the family.

iv. To examine the status of socio-economic, health and educational services in the specified region

\section{HYPOTHESIS}

Hypotheses were tested at 5\% significance level-

i. Ho: There is statistically no significant difference between the null model and the final model 
ii. Ho: There is statistically no significant impact of Household income HH_ Y and Members in the Family Mem_ Fam on the health status of the family Hlth_Stat

iii. Ho: There is statistically no significant correlation between household income and health status of the family

iv. Ho: There is statistically no significant correlations between $\mathrm{HH}_{-} \mathrm{Y}$ and Mem_ Fam with Education status of the family Edu_St

\section{RESEARCH METHODOLOGY}

Research Methodology limelight on the areas related to data collection; tools and techniques by which the research problem was undertaken and further discusses the issues related to data analysis.

\section{Area of Study}

The area of the proposed study was Khandara Gram Panchayat, Multai tehsil of Betul district which is one of the populous tehsils of the district; there are about 160 villages in the sub-district.

\section{Population}

The total population of Multai Tehsil is 2.66,395. 69,200 household resides in this tehsil which is spread across 160 villages and 70-Gram panchayats. More than 550 Gond households reside in nearby villages of Khandara Gram panchayat.

\section{Sample \& Sampling Techniques}

Six villages; Barsali, Guwadi, Mordongri, Bodna, Kumhartak, and Khandara where Gond population was densely populated were selected for the study which falls under Khandara Gram Panchayat of Betul Block. Purposive sampling was used for selecting the villages, where the Gond population was high, later on, Systematic sampling was used for selecting the $\mathbf{1 5 4}$ households from six villages that come under Khandara GramPanchayat.

\section{Respondent (Subject)}

The respondent in the study comprises 'Head of the Gond Family' either male or female. Time to time group discussions also takes place with the tribal people of that community.

\section{Tools}

The proposed study used a standardized questionnaire for collecting data, Factor analysis was used for standardizing the tool. The questionnaire includes $\mathbf{2 0}$ items that were structured in both English and Hindi, but the interviewers interact in Hindi or other dialects to collect viable information.

\section{Variables}

The proposed study tries to understand the influence of household income and members in the family on health status and education status.

\section{Dependent Variable}

Health Status HIt_Stat and Education Status Edu_Stat of the family mentioned as the dependent variable.

\section{Independent Variable}

Members in the family Mem_Fam and monthly income of the household HH_Y considers as an independent variable whose effect on the dependent variable has been studied.

\section{ANALYSIS}

Multiple Correlation and Regression Analysis, Multinomial Logistic Regression and Correlation Regression Analysis were used for analyzing the data in the case of categorical data. Other facts are explored on a percentage basis. Model fit criteria proposed by Bagozzi and Yi (1988) will be used for references.

\section{RESULTS}

The results of the proposed study have been discussed by testing the various hypotheses as discussed in the above section.

I. Ho: There is statistically no significant difference between the null model and the final model

Table 7: Model Fitting Information

\begin{tabular}{lllll}
\hline Model & $\begin{array}{l}\text { Model Fitting } \\
\text { Criteria }\end{array}$ & Likelihood Ratio Tests & \\
& -2 & & & \\
& Likelihood & & LogChi-Square df & Sig. \\
& & & \\
\hline
\end{tabular}




\begin{tabular}{lllll}
\hline Intercept Only & 141.233 & & \\
\hline Final & 43.824 & 97.408 & 12 & .000 \\
\hline
\end{tabular}

Household income (HH_Y) and total members in the family Mem_Fam is impacting on the health status of the family (Hlt_Stat) this is the final model.

Ho: There is statistically no significant difference between the null model and the final model. Since the $p$ value $=0.00$ (Less than 0.05)

Null Hypothesis is rejected; it means that the final model is fit. The final model is more significant than the null model.

Table 8: Goodness-of-Fit

\begin{tabular}{llll}
\hline & Chi-Square & df & Sig. \\
\hline Pearson & 8.042 & 12 & .782 \\
\hline Deviance & 9.258 & 12 & .681 \\
\hline
\end{tabular}

Since the Pearson Value of significance is 0.782 (greater than 0.05), it reflects that the final model is adequately fit.

Table 9: Pseudo R-Square

\begin{tabular}{lc}
\hline Cox and Snell & .469 \\
\hline Nagelkerke & .532 \\
\hline McFadden & .298 \\
\hline
\end{tabular}

The two IV, how much they are showing the variation in DV is explained by Pseudo- R- Square. Cox and Shell= 0.469 (not much variation) Nagelkerke $=0.532$

The two independent variables (IV) are not able to discriminate the health status of the family adequately. The study has to add some more variables to make the model more adequate.

Table 10: Likelihood Ratio Tests

\begin{tabular}{|c|c|c|c|c|}
\hline \multirow[t]{2}{*}{ Effect } & $\begin{array}{l}\text { Model } \\
\text { Criteria }\end{array}$ & \multicolumn{3}{|c|}{ Fitting Likelihood Ratio Tests } \\
\hline & $\begin{array}{l}-2 \\
\text { Likeliho } \\
\text { Reduced }\end{array}$ & $\begin{array}{l}\text { LogChi-Square } \\
\text { of } \\
\text { lodel }\end{array}$ & $\mathrm{df}$ & Sig. \\
\hline Intercept & $43.824^{\mathrm{a}}$ & .000 & 0 & . \\
\hline$\overline{\mathrm{HH}} \_\mathrm{Y}$ & 112.315 & 68.491 & 6 & .000 \\
\hline$\overline{\text { Mem_Fam }}$ & 84.343 & 40.518 & 6 & .000 \\
\hline
\end{tabular}

The chi-square statistic is the difference in -2 log-likelihoods between the final model and a reduced model. The reduced model is formed by omitting an effect from the final model. The null hypothesis is that all parameters of that effect are 0 .

a. This reduced model is equivalent to the final model because omitting the effect does not increase the degrees of freedom.

Ho: There is statistically no significant impact of Household income HH_ Y and Members in the Family Mem_ Fam on the health status of the family Hlth_Stat

The significance value in both the cases; $\mathrm{HH}_{-} \mathrm{Y}$ and Mem_ Fam are 0.000. It shows that both the variables Household income and Family members have a significant impact on the health status of the family.

Table 11: Parameter Estimates

\begin{tabular}{cccccccc}
\hline $\begin{array}{c}\text { Health Status of the } \\
\text { family }\end{array}$ & B & Std. Error & Wald & df & Sig. & Exp(B) & $\begin{array}{c}\text { 95\% Confidence } \\
\text { Interval for Exp(B) }\end{array}$ \\
& & & & & & $\begin{array}{c}\text { Lower } \\
\text { Bound }\end{array}$ & $\begin{array}{c}\text { Upper } \\
\text { Bound }\end{array}$ \\
\hline Intercept & -.596 & .821 & .528 & 1 & .468 & & \\
\hline
\end{tabular}




\begin{tabular}{|c|c|c|c|c|c|c|c|c|c|}
\hline & H_Y $=1.00]$ & 37.520 & 2678.678 & .000 & 1 & .989 & $\begin{array}{l}19719540418292 \\
640.000\end{array}$ & .000 & $b$ \\
\hline & H_Y $=2.00]$ & 19.685 & 1452.523 & .000 & 1 & .989 & 354126374.796 & .000 & $\mathrm{~b}$ \\
\hline & H_Y $=3.00]$ & 3.252 & .897 & 13.151 & 1 & .000 & 25.848 & 4.457 & 149.897 \\
\hline \multirow{7}{*}{$\begin{array}{l}\text { Suffering } \\
\text { from } \\
\text { chronic } \\
\text { disease }\end{array}$} & H_Y=4.00] & $0^{\mathrm{c}}$ & . & . & 0 & . & . & . & . \\
\hline & $\begin{array}{l}\text { [Mem_Fam } \\
=1.00]\end{array}$ & -20.234 & 1452.523 & .000 & 1 & .989 & $1.632 \mathrm{E}-009$ & .000 & $\mathrm{~b}$ \\
\hline & $\begin{array}{l}\text { [Mem_Fam } \\
=2.00]\end{array}$ & -.693 & 1.233 & .316 & 1 & .574 & .500 & .045 & 5.607 \\
\hline & $\begin{array}{l}{[\text { Mem_Fam }} \\
=3.00]\end{array}$ & -1.485 & 1.118 & 1.765 & 1 & .184 & .227 & .025 & 2.026 \\
\hline & $\begin{array}{l}{\left[\mathrm{Mem} \_ \text {Fam }\right.} \\
=4.00]\end{array}$ & $0^{c}$ & . & . & 0 & . & . & . & . \\
\hline & Intercept & $\begin{array}{l}- \\
33.872\end{array}$ & 3433.597 & .000 & 1 & .992 & & & \\
\hline & $\begin{array}{l}{\left[\mathrm{HH} \_\mathrm{Y}=1.00\right.} \\
]\end{array}$ & 54.387 & 4354.871 & .000 & 1 & .990 & $\begin{array}{l}41671835730731 \\
0100000000.000\end{array}$ & .000 & $b$ \\
\hline \multirow{4}{*}{$\begin{array}{l}\text { Suffering } \\
\text { from ma } \\
\text { nutrition }\end{array}$} & $\begin{array}{l}\text { [HH_Y }=2.00 \\
]\end{array}$ & 36.360 & 3728.192 & .000 & 1 & .992 & $\begin{array}{l}61767716387298 \\
87.000\end{array}$ & .000 & $b$ \\
\hline & $\begin{array}{l}{\left[\mathrm{HH} \_\mathrm{Y}=3.00\right.} \\
]\end{array}$ & 19.533 & 3433.597 & .000 & 1 & .995 & 304148148.110 & .000 & $\mathrm{~b}$ \\
\hline & [HH_Y=4.00 & $0^{\mathrm{c}}$ & . & . & 0 & . & . & . & . \\
\hline & $\begin{array}{l}\text { [Mem_Fam } \\
=1.00]\end{array}$ & -2.634 & 1452.523 & .000 & 1 & .999 & .072 & .000 & $\mathrm{~b}$ \\
\hline \multicolumn{2}{|c|}{$\begin{array}{l}\text { Mem_Fam } \\
=2.00]\end{array}$} & 15.728 & .933 & $\begin{array}{l}284.01 \\
7\end{array}$ & 1 & .000 & 6770451.457 & $\begin{array}{l}1086987 \\
.104\end{array}$ & $\begin{array}{l}42170705 \\
.378\end{array}$ \\
\hline \multicolumn{2}{|c|}{$\begin{array}{l}\text { [Mem_Fam } \\
=3.00]\end{array}$} & 14.854 & .000 & . & 1 & . & 2824840.594 & $\begin{array}{l}2824840 \\
.594\end{array}$ & $\begin{array}{l}2824840 . \\
594\end{array}$ \\
\hline \multicolumn{2}{|c|}{$\begin{array}{l}\text { [Mem_Fam } \\
=4.00]\end{array}$} & $0^{\mathrm{c}}$ & . & . & 0 & . & . & . & . \\
\hline
\end{tabular}

a. The reference category is Medically Fit.

b. The floating-point overflow occurred while computing this statistic. Its value is therefore set to system missing.

c. This parameter is set to zero because it is redundant.

The medically fit category is taken as the reference category. The study is comparing chronic disease and malnutrition to medically fit. The result is concluded on the basis of B value and significance level.

Households whose income is up to Rs.5k are 37.520 times suffering from chronic disease than medically fit whereas households whose income is more than $20 \mathrm{k}$ are almost not suffering from any chronic disease, it means that they are medically fit. When the family members are up to four, in such cases families are 20.234 times less suffering from the chronic disease it means they are more medically fit. In the case of household income to suffering from chronic disease first, two cases are insignificant whereas in the third case it is significant whereas family members to chronic disease in the first three cases it is statistically insignificant.

In another case Households whose income is up to Rs.5k are 54.387 times suffering from malnutrition than medically fit whereas households whose income is more than 20k are almost not suffering from malnutrition, it means that they are medically fit. When the family members are up to four, in such cases families are 2.634 times less suffering from malnutrition than medically fit, whereas when family members are up to 12, in such cases families are 14.854 times more suffering from malnutrition problem than medically fit. In case of household income to suffering from malnutrition first two cases are insignificant, while the third one is significant whereas family members to malnutrition first case are 
statistically insignificant whereas family members are up to 8 it is statistically significant.

Table 12: Classification

\begin{tabular}{lllll}
\hline \multirow{2}{*}{ Observed } & \multicolumn{4}{c}{ Predicted } \\
\cline { 2 - 5 } & $\begin{array}{l}\text { Suffering from } \\
\text { chronic disease }\end{array}$ & $\begin{array}{c}\text { Suffering from } \\
\text { malnutrition }\end{array}$ & Medically Fit & Percent Correct \\
\hline Suffering from chronic disease & 50 & 6 & 8 & $78.1 \%$ \\
\hline Suffering from malnutrition & 33 & 15 & 9 & $26.3 \%$ \\
\hline Medically Fit & 5 & 0 & 28 & $84.8 \%$ \\
\hline Overall Percentage & $57.1 \%$ & $13.6 \%$ & $29.2 \%$ & $60.4 \%$ \\
\hline
\end{tabular}

The overall percentage of classification is $60.40 \%$ it means that classification is not well adequate. The study has to consider some other variables in order to the identified the health status of the family because household income and members of the family don't provide a clear picture of the health status of the tribal families.

II. Ho: There is statistically no significant correlation between household income and health status of the family

Table 13: Model Summary

\begin{tabular}{lllll}
\hline Model & R & R Square & $\begin{array}{c}\text { Adjusted R } \\
\text { Square }\end{array}$ & $\begin{array}{c}\text { Std. Error of the } \\
\text { Estimate }\end{array}$ \\
\hline 1 & $.240^{\mathrm{a}}$ & .057 & .051 & .75020 \\
\hline
\end{tabular}

a. Predictors: (Constant), Income of the Family

The correlation between HH_Y to Hlt_Stat is 0.240 it reflects positive correlation, there is a positive correlation between household income and health status and relatively it shows a weaker correlation between the two as it is small.

Table 14: Coefficients ${ }^{\mathrm{a}}$

\begin{tabular}{|c|c|c|c|c|c|}
\hline \multirow[t]{2}{*}{ Model } & \multicolumn{2}{|c|}{ Unstandardized Coefficients } & $\begin{array}{l}\text { Standardized } \\
\text { Coefficients }\end{array}$ & \multirow[t]{2}{*}{$\mathrm{t}$} & \multirow[t]{2}{*}{ Sig. } \\
\hline & B & Std. Error & Beta & & \\
\hline (Constant) & 1.302 & .174 & \multirow[b]{3}{*}{.240} & 7.480 & .000 \\
\hline \multicolumn{3}{|l|}{1} & & & \\
\hline The income of the Family & .208 & .068 & & 3.044 & .003 \\
\hline
\end{tabular}

a. Dependent Variable: Health Status of the family

b. Predictors: (Constant), Income of theFamily

As p value $=0.003$ (Less than 0.05$)$, it reflects a statistically significant correlation between household income and health status of the Gond family. The null hypothesis is rejected on these grounds. Regression Equation $\mathrm{Y}=\mathrm{a}+\mathrm{b} \mathrm{X}$ (Y- DV Hlt_Stat, X-IV HH_Y)

$\mathrm{a}=1.302$ (Intercept) and $\mathrm{b}=0.208$ (Slope)

Therefore the Regression equation will be $\mathrm{Y}=1.302+0.208 \mathrm{X}$

III. Ho: There is statistically no significant correlations between $\mathrm{HH}_{-} \mathrm{Y}$ and Mem_ Fam with Education status of the family Edu_Stat

Table 15: Model Summary

\begin{tabular}{lllll}
\hline Model & R & R Square & Adjusted R Square & $\begin{array}{c}\text { Std. Error of the } \\
\text { Estimate }\end{array}$ \\
\hline 1 & $.631^{\mathrm{a}}$ & .398 & .390 & .38957 \\
\hline
\end{tabular}

a. Predictors: (Constant), Income of the Family, Members in the Family

The overall correlation between HH_Y and Mem_Fam with Edu_Stat is 0.631 it shows a high positive correlation. R square factor shows that both the independent variables account for only $3.98 \%$ of the variation in the Edu_Stat. or $96 \%$ of the variation in the education status of the family can be explained by other factors. 
Table 16: ANOVA $^{\mathrm{a}}$

\begin{tabular}{lllllll}
\hline Model & & Sum of Squares & df & Mean Square & F & Sig. \\
\hline \multirow{2}{*}{1} & Regression & 15.168 & 2 & 7.584 & 49.973 & $.000^{\mathrm{b}}$ \\
\cline { 2 - 5 } & Residual & 22.916 & 151 & .152 & \\
\hline & Total & 38.084 & 153 & & & \\
\hline
\end{tabular}

a. Dependent Variable: Education Status of the family

b. Predictors: (Constant), Income of the Family, Members in theFamily

F-value for R square (Multiple R square) is 49.973. $\mathrm{p}$ value=0.000 $(<0.05)$. The null hypothesis is rejected; it shows that two of these correlations are statistically significant with Edu_Stat.

Table 17: Coefficients ${ }^{\mathrm{a}}$

\begin{tabular}{|c|c|c|c|c|c|c|}
\hline \multirow{2}{*}{\multicolumn{2}{|c|}{ Model }} & \multicolumn{2}{|c|}{ Unstandardized Coefficients } & \multirow{2}{*}{$\begin{array}{l}\begin{array}{c}\text { Standardized } \\
\text { Coefficients }\end{array} \\
\text { Beta }\end{array}$} & \multirow[t]{2}{*}{$\mathrm{T}$} & \multirow[t]{2}{*}{ Sig. } \\
\hline & & B & Std. Error & & & \\
\hline & (Constant) & 1.028 & .097 & & 10.631 & .000 \\
\hline \multirow[t]{2}{*}{1} & Members in the Family & -.242 & .044 & -.427 & -5.441 & .000 \\
\hline & Income of the Family & .440 & .044 & .783 & 9.979 & .000 \\
\hline
\end{tabular}

a. Dependent Variable: Education Status of the family

When both the independent variables are zero at that time Edu-Stat is 1.028, in each unit of increase in members of the family, education status of the family decreases by 2.42 whereas each unit increase in income, education status of the family increases by 0.440 .

\section{IV.Other facts}

Some additional facts related to the composite index of the Gond tribe are based on the data collected by the help of the tool used in the proposed study are discussed under this head.

\section{A. Socio-Economic Status: Family Size}

On the basis of data collected from 154 households; Small family (1-4 Members) were 40 (26\%), Medium family (5-8 Members) 54 (35.10\%), Large family (9-12 Members) 52 (33.80\%) and Very Large family (More than 12 Members) 8 $(5.20 \%)$.

\section{The income of the Household}

On the basis of data collected from 154 households; Income (Within 5K) were $22(14.30 \%)$, Income (5K-10K) 70 (45.51\%), (10K-20K) 42 (23.30\%) and Income (Above 20K) 20 (13.00\%).

\section{Land Holdings by the HH}

On the basis of data collected from 154 households; Landless were 61 (39.61\%), Marginal Land (Below 1 Acre) 52 (33.76\%), Medium (1-5 Acre) 26 (16.88\%) and Large (Above 5 Acre) 15 (9.74\%).

\section{Condition of Houses}

On the basis of data collected from 154 households; Dilapidated (Ruined) was 32 (20.77\%), Tile (Khaprail) 48 (31.16\%), Semi furnished House 43 (27.92\%) and Furnished House (Brick) 31 (20.12\%).

\section{B. Health and Education Status Household Health and education}

$64(41.60 \%)$ households suffering from chronic diseases, $57(37 \%)$ suffering from malnutrition problems and only $33(21.40 \%)$ households found medically fit. In 69 (44.80\%) cases children are not going to school whereas 85 (55.20\%) cases it was found that children were going to school for attaining education.

\section{Health and Educational Services}

$89(57.80 \%)$ households were not satisfied with medical services in their region. $7(4.50 \%)$ graded good, $70(45.50 \%)$ graded average/ normal and 77(50\%) households graded poor/ worst medical services in their region. 62(40.30\%) households were availing medical benefits whereas 92(59.70\%) households were not availing medical benefits from government programs/ schemes. $117(76.0 \%)$ households were availing educational benefits whereas 37(24.0\%) households were not availing educational benefits from government programs/ schemes. 


\section{DISCUSSIONS}

Since the present study is limited to the Gond tribe of Betul district, M.P., covering general facts related to health and education. The upcoming studies would be conducted in tribal concentrated areas and their related problems. These are the specific problems that can be covered in future studies.

- Awareness of Family Planning programs among women; methods used for family planning.

- Facts related to the diet pattern of Men and Women in Tribal areas.

- Sources of drinking water and toilet facilities, in order to study the effectiveness of 'Swachh Bharat Abhiyan'.

- Enrolment of boys and girls students in Primary, Upper- Primary and Secondary classes, in order to study the effectiveness of other educational programs running by the government.

- Indigenous knowledge related to medicine and other allied areas, which do not yet explore will be added advantage to use tribal knowledge in finding the solution to more complex ones.

Thus, in the end, the understudy highlighted the major side that it is the duty of the Government to make the tribal people aware about the programs and schemes running by them for the tribal welfare in different areas and educate them about their rights, in this way the condition of the tribal people will be improved to an extent.

\section{CONCLUSION \& SUGGESTIONS}

Education and Health accelerate the process of human development backed up by sound financial position but in case of Gond Tribe in Betul district, the condition is pathetic as Gond households are facing several problems like; illiteracy, low income, malpractices among youths, lack of awareness about the Government Programs/ Policies and may others. It is suggested that if future studies will cover the concerned issues it will explore astonishing facts which will help the Government and other agencies working in Health and Education sectors in policy formulation and implementing their suggestions for the tribal welfare. The government should run programs to reduce the cases of contagious diseases from hotspots areas in tribal areas, it requires immediate attention.

The proposed work has studied the Gond tribe of Betul district, Madhya Pradesh; further studies will be conducted in other new areas that explore some specific tribal related problems supported by plausible solutions. Gond tribe have to move according to the need of the time but a part of it they have to transmit their cultural values to their offspring's so that their traditional knowledge transfer from one generation to other, otherwise Gond tribe will lose their originality due to effusion of modernization.

\section{ACKNOWLEDGMENT}

The study has not received any financial support from any agencies or any other sources. Mr. Chetan Bihare (BA B.Ed. student, Deptt. of Education, D.H.S.G.V.V. Sagar, M.P.) and his colleagues have helped in collecting information, our resource persons help a lot in collecting data and facts while interacting with the Gond community as they belong to the same villages, it makes our field-work easier and comfortable. The greatest outcome of this study is our sweetest memories, in the form of time spent and personal relations with Gond families; it will be a valuable asset for any researcher.

\section{REFERENCES}

1. Bagozzi, R.P. \& Yi. Y. (1988). On the evaluation of structural equation models. Journal of the Academic of Marketing Science, 16(1), 74-94. https://doi.org/10.1007/BF02723327

2. Basu, S. (2000). Dimension of Tribal Health in India.Health and Population- Perspectives and Issues, 23(2), 61-70.

3. Dash, A. (2013). Relates on Tribal Education and Health: Evidence from Rural Odisha, India.International Research Journal of Social Sciences, 2(11), November, 11-16.

4. Dhargupta, A., Goswami, A. et al. (2009). Study on the Effect of Socio-economic Parameters on Health Status of the Toto, Santal, Sabarand Lodha Tribes of W.B. India. Studies of Tribes and Tribals, 7 (1), 31-38. https://doi.org/10.1080/0972639X.2009.11886592

5. Indian Council of Medical Research. (1990). Nutritional Requirements and Recommended Dietary Allowances for Indians. New Delhi: ICMR.

6. Lokur Committee (1965). The Report of the Advisory Committee on the Revision of the Lists of Scheduled Castes and Scheduled Tribes. Department of Social Security. Government of India: New Delhi. p.7

7. Ministry of Health and Family Welfare and Ministry of Tribal Affairs. (2018, Oct.). Tribal Health in India Bridging the Gap and a Roadmap for the Future (2018). Government of India: New Delhi. 1-33, 121

8. Ministry of Health and Family Welfare. (2017, Dec.). National Family Health Survey-4(2015-16). Mumbai: IIPS, p.197. Retrieved from http://rchiips.org/nfhs/NFHS-4Reports/India.pdf

9. Ministry of Human Resource Development. Department of School Education \& Literacy Statistics Division. (2018). Educational Statistics at a Glance. Government of India: New Delhi, 60-64. 
10. Ministry of Statistics \& Programme Implementation. (2013, Jan-Dec).Household Ownership and Operational Holdings in India. NSSO (70 ${ }^{\text {th }}$ Round, Report No. 571). Government of India: New Delhi. p i, 14.

11. Ministry of Statistics \& Programme Implementation. (2018, July-Dec). Drinking Water, Sanitation, Hygiene and Housing Condition in India. NSSO (76 ${ }^{\text {th }}$ Round, Report No. 584). Government of India: New Delhi. 142-143.

12. Ministry of Tribal Affairs. (2013).Statistical Profile of Scheduled Tribes in India. Statistics Division. Government of India: New Delhi. p. 275

13. Ministry of Tribal Affairs. (2013. Statistical Profiles of Scheduled Tribes in India.Statistical Division. Government of India. New Delhi: 1 -39.

14. Mitra, M. \&Sahu, P. K. et al. (2007). Nutritional and Health Status of Gond and Kawar Tribal Pre-school Children of Chhattisgarh, India.Journal of Human Ecology, 21(4), 293- 299. https://doi.org/10.1080/09709 274.2007.11905988

15. Office of Registrar General \& Census Commissioner India. (2011) Census Info. Ministry of Home Affairs, Government of India: New Delhi. Retrieved from http://censusindia.gov.in/Tables_Publish ed/SCST/ST\% 20Lists.pdf

16. Office of Registrar General \& Census Commissioner India. (2011).Census Info. Ministry of Home Affairs, Government of India: New Delhi. Retrievedfrom http://www.censusindia.gov.in/2011census/HLO/HH14.html

17. Pradhan, S. \& Sharma, K. (2011). Nutritional Status of Bhil Tribal Children in Madhya Pradesh, India: A CrossSectional Study.Studies of Tribes and Tribals, 9(1), 37-40. https://doi.org/10.1080/0972639X.2011.11886626

18. Rao, H. (1986). Health and Nutritional Status of Tribal in Madhya Pradesh. Hyderabad: National Institute of Nutrition.

19. Retrieved from https://shodhganga.inflibnet.ac.in/bitstream/10603/11218/9/09 chapter\%201.pdf

20. Sharma, A. \&Dubey, R. (2017). An Exploratory Study of Education and Health Status of Gond Tribe: With Special Reference to Banda Tehsil of Sagar District, M.P.Quest, 11(2), 144-151. https://doi.org/10.5958/22490035.2017 .00019 .5

21. Sujatha, K. (1999). Working document in the series: Strategies of education and training for disadvantaged groups, Education of India Scheduled Tribes: A Study of Community Schools in the District of Vishakhapatnam, A.P.(183-186), Paris (Indian Council of Medical Research , 1990): IIEP (UNESCO).

22. Swaminathan, S.(2014).Taking Healthcare to India's Remote Tribes - The Hindu (Online). Updated on 19 July 2016, 1-4.

23. Weiner, J.S. \&Lourie, J. A. (1981). Practical Human Biology. Oxford London: Academic Press.

24. World Health Organization (1995). Physical Status: The Use and Interpretation of Anthropometry. WHO Technical Report No. 854. Geneva: WHO.

\section{FURTHER READINGS}

Ministry of Tribal Affairs.(2014, May).Report of the High level Committee on Socio-economic, Health and Educational Status of Tribal Communities of India. Government of India: New Delhi. 